\title{
Muscle pigmentation of Nile tilapia (Oreochromis niloticus) fed on crude palm oil incorporated fish feed
}

\author{
D.S.A.D.S. Wickramanayake ${ }^{1}$, Nishantha K. Kalutharage ${ }^{2 *}$ and P.R.T. Cumaranatunga ${ }^{1}$ \\ ${ }^{1}$ Department of Fisheries and Aquaculture, Faculty of Fisheries and Marine sciences \& \\ Technology, University of Ruhuna, Matara, Sri Lanka \\ ${ }^{2}$ Department of Chemistry, Faculty of Science, University of Ruhuna, Matara, Sri Lanka
}

*Corresponding author (knishantha@ chem.ruh.ac.lk)

ORCID ID: https://orcid.org/0000-0003-1783-4530

Received: 04.05.2021 Revised: 11.08.2021 Accepted: 03.09.2021 Online: 15.09.2021

\begin{abstract}
The effects of diets containing crude palm oil on muscle pigmentation and deposition of carotenoids in tilapia (Oreochromis niloticus) was studied. A total of 135 advanced fingerlings with an average body weight and standard length of $9.11 \pm 4.78 \mathrm{~g}$ and $8.1 \pm 0.8 \mathrm{~cm}$, respectively were stocked in tanks for 8 weeks and fed with formulated diets containing crude palm oil (CPO) as the oil component. Weight, standard length, and carotenoid levels in fish were measured biweekly. Muscles of fish fed with the control diet and CPO incorporated diets had carotenoid levels of $0.14 \pm 0.03 \mu \mathrm{g} / \mathrm{g}$ and $0.28 \pm 0.01 \mu \mathrm{g} / \mathrm{g}$, respectively. Skin of the fish had carotenoid levels of $3.24 \pm 0.02 \mu \mathrm{g} / \mathrm{g}$ in the control and $6.06 \pm 0.03 \mu \mathrm{g} / \mathrm{g}$ in the treatment. According to the results $3 \% \mathrm{CPO}$ incorporated diet had a significant effect on enhancing flesh colour in tilapia. The sensory evaluation indicated that the flesh of CPO fed tilapia fillets were more attractive than the fillets of fish fed control diet. CPO oil is recommended as a natural food colourant for improving flesh quality of Nile tilapia fillets.
\end{abstract}

Keywords: Orochromis niloticus, Carotenoids, $\beta$-carotene, pigmentation

\section{INTRODUCTION}

Carotenoids are a group of phytochemicals responsible for yellow to orange colour of fish (Rebecca et al. 2014). These pigments are derived from dietary sources because the fish are unable to biosynthesize carotenoids (Foss et al. 1984). The orange-pink color of fish fillets is considered a visual indication of "quality" by consumers. Hence, supplementing feed with astaxanthin or canthaxanthin to obtain red-colored flesh is a common practice in fish farming. Carotenoids are known as pro-vitamin $\mathrm{A}$ and immunoregulator which absorb light in the 400-500 $\mathrm{nm}$ range of the visible spectrum (Rebecca et al. 2014; Foss et al. 1984; García-Chavarría et al. 2013.). Carotenoids are amenable for development of the skin colour of ornamental fish as well as the colour of flesh of food fish (Jintasataporn and Yuangsoi 2012). Synthetic carotenoids are used as dietary supplements to enhance the pigmentation of fish (Kalinowski et al.
2005). Many fish accumulate carotenoids in their integument, flesh and gonads. The effectiveness of deposition and pigmentation of carotenoids is source and species specific. Certain fish have the ability to convert one form of carotenoids into another (Kang and Ha 1994).

In fish, there is no common mechanism for the metabolism of carotenoids and their subsequent derivatives (Das and Biswas 2016). Scientists believe there is a metabolic pathway for carotenoids in the liver and intestines (Aas et al. 1999). Selvakumar et al. (2011) have classified fish into two groups based on the capacity of metabolization of carotenoids. The first type of fish requires an inclusion of specific oxygenated derivatives in to their diet as they are unable to oxidation of ionone. The second type of fish such as gold fish or the fancy red carp can oxidate 4 and $4^{\prime}$ positions of ionone ring and hence have the potentiality of conversion of zeaxanthin and lutein to astaxanthin (Gouveia et al. 2003). 


\section{D.S.A.D.S. Wickramanayake et al.}

As the aquaculture feed industry seeks natural, environmentally friendly sources of pigments to improve colour and to enhance consumer acceptability, there is a great potential for using natural carotenoids in the industry. It paves the way for many aquaculture feed industries to promote their products as natural with a clear shift away from synthetic ingredients and colourants (Rebecca et al. 2014). Natural carotenoids derived from animals such as crustaceans are limited in supply as there is a declining trend in catches (Gupta et al. 2007). Plant-based foods such as yellow corn, corn gluten meal, vegetable oils and red pepper are also used as natural sources of carotenoids in aquaculture feed formulations. Crude palm oil (CPO) contains the highest known concentration of carotenoids from vegetable oils (Zeb and Mehmood 2004).

$\mathrm{CPO}$ is a lipid, extracted from the fleshy orangered mesocarp of the fruits of the oil palm tree Elaeis guineensis (Zaliha et al. 2015). It is the world's richest natural plant source of retinol, which is a kind of carotene (Jain et al. 1990). CPO (known as red palm oil), can be extracted either by wet or dry processes (Mancini et al. 2015). As it has a balanced fatty acid composition, the level of saturated fatty acids is almost equal to the levels of unsaturated fatty acids (Koushki et al. 2015). It contains both healthy and beneficial compounds such as triacylglycerols, vitamin E, carotenoids, phytosterols, as well as impurities such as phospholipids, free fatty acids, gums, and lipid oxidation products (Mancini et al. 2015).

The main carotenes present in CPO are $\beta$ carotene $(56 \%)$ and $\alpha$-carotene $(35 \%)$ which are pro-vitamin A. Natural antioxidant, tocopherol and tocotrienol contents are 600 and $1200 \mathrm{ppm}$ respectively (Koushki et al. 2015). The fraction obtained from refining, bleaching and deodorization of CPO is palm olein. The oil obtained after the refining processes is paint yellow, soft and stable (Mancini et al. 2015).

Red Palm Oil (RPO) and palm olein (PO) have good oxidative stability due to the presence of natural antioxidants and the absence of linolenic acid (Koushki et al. 2015).

Tilapia is a widely farmed freshwater fish in the world. The consumer preferences of tilapia could be increased by changing the colour of flesh. Yanar et al. (2007) conducted an experiment using three carotenoid sources; marigold flower, synthetic astaxanthin and red pepper, and the highest carotenoid level was observed in the fish flesh with synthetic astaxanthin followed by red pepper and marigold flower. The effect of different carotenoids present in tilapia fish (Oreochromis niloticus) fed for 80 days with feed containing astaxanthin and the bacterial Rubrivivax gelatinosus have resulted in increasing carotenoid concentration and the redness in the fish fillets (Valente et al. 2016).

The present study investigated value addition of Oriochromis niloticus fillet by carotenoid pigmentation on muscle using $\beta$-carotene rich sources of crude palm oil (CPO) in order to increase consumer preference.

\section{METHODOLOGY}

A total of 180 advanced fingerlings of Nile tilapia (O. niloticus) $(\sim 7 \mathrm{~cm}$ of standard length) was obtained from Udawalawe tilapia breeding centre, Sri Lanka. Fingerlings were transported in oxygenated polythene bags to aquarium and acclimatized for a period of two weeks. During acclimatization period, fingerlings were kept in 4 fiber-glass tanks $(380 \mathrm{~L})$ and fed a commercial fish feed, to the level of satiation.

Circular fiberglass tanks ( $375 \mathrm{~L})$ were cleaned and filled with de-chlorinated water up to $2 / 3$ of the tank volume $(250 \mathrm{~L})$. After acclimation, fingerlings, each with a body weight of $19.11 \pm 4.78 \mathrm{~g}$ and a standard length of $8.1 \pm 0.8 \mathrm{~cm}$, were selected and randomly stocked into six fibre-glass tanks with stocking density of 15 fingerlings per tank.

The diets contained $35 \%$ protein and were prepared using fish meal, soybean meal, wheat flour, coconut meal, vitamin and mineral mixture and palm olein (PO) for control diet. PO was replaced by $\mathrm{CPO}$ in preparing the test diet.

The required amount of each ingredient was weighed (Table 1) and mixed with hot water $\left(50^{\circ} \mathrm{C}\right)$. Feed was prepared according to literature procedures (Craig et al. 2017).

Prepared test diets were crumbled into desirable size according to the size of fish's mouth gape. Fish were fed three times a day at 09.00, 13.00, 17.00 hours upto satiation. Three tanks fed with diet contain CPO and the other three tanks were fed with diet contain PO as the control diet. Daily feed consumption was measured separately for each tank.

During the period of the experiment, a constant water volume was maintained in all tanks. Each tank 
D.S.A.D.S. Wickramanayake et al.

was continuously aerated and cleaned daily before the first feeding by siphoning off accumulated waste materials. Approximately $100 \mathrm{~L}$ of water in each tank was replaced with de-chlorinated tap water.

Table 1 Diet formulation and proximate composition of experimental diets

\begin{tabular}{lcc}
\hline Ingredients & Control & CPO \\
\hline Fish meal & 38 & 38 \\
$\begin{array}{l}\text { Soybean } \\
\text { meal }\end{array}$ & 16 & 16 \\
$\begin{array}{l}\text { Coconut } \\
\text { meal }\end{array}$ & 11 & 11 \\
$\begin{array}{l}\text { Wheat flour } \\
\text { Vitamin }\end{array}$ & 31 & 31 \\
and Mineral & 1 & 1 \\
mix & & \\
$\begin{array}{l}\text { Oil } \\
\text { Proximate composition (\% dry matter) }\end{array}$ \\
$\begin{array}{l}\text { Crude } \\
\text { protein }\end{array}$ & $37.03 \pm 0.02$ & $37.11 \pm 0.04$ \\
$\begin{array}{l}\text { Crude lipid } \\
(\%)\end{array}$ & $4.28 \pm 0.04$ & $4.47 \pm 0.11$ \\
$\begin{array}{l}\text { Ash }(\%) \\
\text { Moisture } \\
(\%)\end{array}$ & $10.04 \pm 0.02$ & $10.45 \pm 0.04$ \\
\hline
\end{tabular}

Prepared test diets were crumbled into desirable size according to the size of fish's mouth gape. Fish were fed three times a day at $09.00,13.00,17.00$ hours upto satiation. Three tanks fed with diet contain CPO and the other three tanks were fed with diet contain PO as the control diet. Daily feed consumption was measured separately for each tank.

During the period of the experiment, a constant water volume was maintained in all tanks. Each tank was continuously aerated and cleaned daily before the first feeding by siphoning off accumulated waste materials. Approximately $100 \mathrm{~L}$ of water in each tank was replaced with de-chlorinated tap water.

\section{Data collection of fish growth performance}

Initial length $(\mathrm{cm})$ and weight $(\mathrm{g})$ of fish stocked in the treatment and control tanks were measured and repeated biweekly. The liver and somatic weights of each dissected fish in each tank were measured biweekly. Percent length gain (LG), percentage weight gain (WG), specific growth rate (SGR) and survival rate were determined as described by Dedeke et al. (2013), Feed conversion ratio (FCR) and feed conversion efficiency (FCE) were calculated by the formulae described by Craig et al. (2017). Protein efficiency ratio (PER) and percentage average daily gain (ADG) were calculated according to formulae described by De Silva et al. (1994) for each fish during the experiment. The feed consumption was calculated using the formula put forward by Güroy et al. (2012). The Hepato-somatic index (HSI) of fish was determined as described by Sadekarpawar and Parikh (2013).

\section{Crude protein}

A $0.5-1.0 \mathrm{~g}$ of dried sample (fish and diet) was used to analyse crude protein by AOAC (2003) method by Micro-kjeldhal apparatus.

\section{Crude lipid}

Crude lipid content was determined by Folch method using dried and ground sample $(0.2 \mathrm{~g})$ of flesh of fish Folch et al. (1957).

\section{Total carotenoid content in flesh and skin}

Total carotenoid content in flesh and skin of fish was determined using the method described by Yanar et al. (2007). Fish were sacrificed without using chemicals. Flesh and skin were separated and ground separately. Ground skin and flesh samples weight of $1 \mathrm{~g}$ were transferred in to dry glass bottles separately. A volume of $10 \mathrm{~mL}$ acetone was added and mixed with skin and flesh samples Anhydrous $\mathrm{Na}_{2} \mathrm{SO}_{4}(2 \mathrm{~g})$ was added to the mixture was and it was centrifuged at $5000 \mathrm{rpm}$ for 5 minutes. The sealed glass tubes were then stored at $4^{\circ} \mathrm{C}$. After 3 days, the supernatant of the extract was carefully drained off, and the absorbance was measured at $450 \mathrm{~nm}$ using UV-Visible spectrophotometer (HACH, DR3900).

\section{Saponification value}

Saponification value (as $\mathrm{mg} \mathrm{KOH} / 1 \mathrm{~g}$ of oil) was determined by ASTM D558-95 (2017) method using 1.5-2.0g sample.

\section{Sensory Evaluation}

Sensory evaluation was performed by displaying the samples of fish fillets obtained from fish fed 


\section{D.S.A.D.S. Wickramanayake et al.}

with the control and experimental feeds without providing any identification labels. The experts recorded their preference along a four-point hedonic scale that varied from 1 (not attractive) to 4 (very attractive).

\section{Statistical analysis}

All the data were tested for normality of distribution and homogeneity of variance. Data on pigment levels of fish, standard length and weight which were recorded separately for each test diet were analysed by Randomized block ANOVA from SPSS 16. The significant differences between test diets on WG, LG, SGR, FCR, FCE, PER, feed consumption (FC) and hepato somatic index (HSI) were determined using t-test at minimum significance level of $\mathrm{p}<0.05$.

\section{RESULTS AND DISCUSSION}

\section{Daily Feed Consumption}

The mean daily feed consumption of fish fed experimental diet and the control diet is given in Table 2. The mean daily feed consumption was $4.63 \pm 0.58$, and $4.23 \pm 0.50$ for control and CPO diet, respectively, which were significantly different among different treatments $(\mathrm{p}<0.05)$. Figure 1 illustrates the mean feed consumption of fish during the study period.

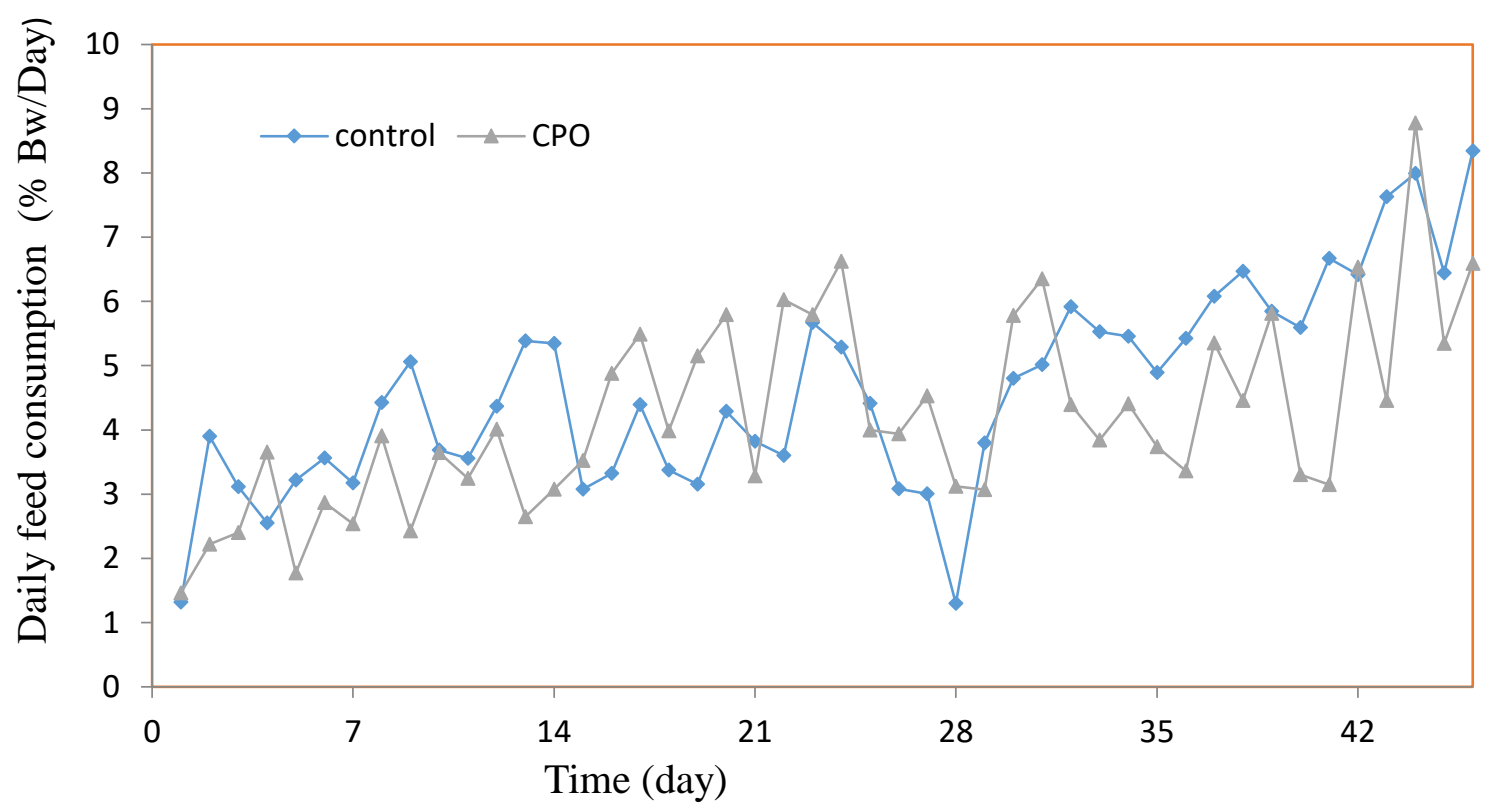

Figure 1 Daily feed consumption of fish in each experimental diet.

\section{Growth parameters}

Growth parameters of fish fed control diet and test diet are tabulated in table 2. The mean total body length (SL) of fish ranged from $10.8 \pm 0.7$ to $11.0 \pm 0.1 \mathrm{~cm}$ at the end of the experiment. Similarly, the mean total body weight is ranging from $45.14 \pm 8.54$ to $48.33 \pm 12.07 \mathrm{~g}$. Length gains (\%LG) of fish fed with control diet and the test diet were $6.1 \pm 0.5 \%$ and $6.5 \pm 1.25 \%$, respectively during the experimental period. The mean percentage weight gain has a similar trend which has the values of 63.4 $\pm 11.2 \%$ for the CPO diet. There were no significant differences of SL, final weights of fish between the control and experimental diet.
The final mean specific growth (\%SGR) rates of fish at the end of the 8-week period fed with control and CPO incorporated diet were $2.02 \pm 0.13 \%$ and $1.96 \pm 0.39 \%$, respectively. There were no significant differences between the 2 types of treatments.

Percentage WG and LG were usually considered as the most important measurements of the productivity of experimental feeds. In the present study, WG and LG were not significantly affected by the different diets. Accoring to $\mathrm{Hu}$ et al. (2006), Nile tilapia fed diets supplemented with $\beta$ carotene showed gradual increase of weight. Similar results have published showing the effect of feeding 


\section{D.S.A.D.S. Wickramanayake et al.}

four carotenoids sources; commercially available astaxanthin, Dunaliella salina extract, crayfish meal (Cherax quadricarinatus) and Squilla sp. meal on growth performance, stress resistance, lipid oxidation and carotenoids pigmentation in the flesh of red tilapia (Oreochromis sp.). These studies that were conducted for a period of 14 weeks showed highly significant differences from the control treatment in carotenoids flesh content, survival rate and growth performances. Compared to other groups, Tilapia fed astaxanthin incorporated diet had been exhibited higher resistance to stress test (Arous et al. 2014).

According to the results $\mathrm{CPO}$ had the highest crude protein, lipid, and fatty acids as well as the TCL. Compared to the test diet, a higher growth was not shown by the fish fed with CPO diet.

There were no significant differences in growth between the fish fed with control and test diets due to same nutrient content in both diets. According to Valente et al. (2016), no significant differences were observed in final body weight, specific growth rate or voluntary feed intake between Nile tilapia fed with diets treated with lutein rich Ulva spp. and the control.

\section{Feed Conversion Ratio (FCR)}

The higher FCR value of $1.78 \pm 0.12$ was observed in the fish fed control diet while FCR value of fish fed test diet was 1.19 \pm 0.12 (Table 2). However, they were not significantly different. FCR is an indicator of feed but may also include the performance of the person feeding the fish, the fishes' health, and cost effectiveness of using a particular feed (Luzzana et al. 2003). The lowest FCR value was shown by fish in $\mathrm{CPO}$ treatments.

\section{Feed Conversion Efficiency (FCE)}

In the present study, the mean FCE values for control and test diets were $40.01 \pm 11.18$ and 46.74 \pm 7.53 , respectively (Table 2) and they were not significantly different $(\mathrm{p}>0.05)$. This indicates that the fish growth had not been influenced by the amount of carotenoids used in oil samples.

Table 2 Growth performance of fish in each test diet.

\begin{tabular}{lll}
\hline Parameter & Control diet & CPO diet \\
\hline Initial length (SL-cm) & $8.0 \pm 0.8^{\mathrm{a}}$ & $7.8 \pm 0.6^{\mathrm{a}}$ \\
$\begin{array}{l}\text { Final length SL-cm } \\
\text { Initial weight (g) }\end{array}$ & $10.9 \pm 0.9^{\mathrm{a}}$ & $10.8 \pm 0.7^{\mathrm{a}}$ \\
$\begin{array}{l}\text { Final weight (g) } \\
\text { percent Length gain (SL) } \\
\text { percent Weight gain (WG) }\end{array}$ & $48.38 \pm 0.00^{\mathrm{a}}$ & $18.60 \pm 0.00^{\mathrm{a}}$ \\
$\begin{array}{l}\text { Daily feed consumption } \\
\text { (BW/Day) }\end{array}$ & $4.62 \pm 1.0^{\mathrm{a}}$ & $45.15 \pm 0.00^{\mathrm{a}}$ \\
$\begin{array}{l}\text { Specific growth rate } \\
\text { (SGR) }\end{array}$ & $2.01 \pm 0.18^{\mathrm{a}}$ & $6.5 \pm 1.2^{\mathrm{a}}$ \\
$\begin{array}{l}\text { Feed conversion ratio } \\
\text { (FCR) }\end{array}$ & $1.41 \pm 0.07^{\mathrm{a}}$ & $57.76 \pm 8.75^{\mathrm{a}}$ \\
$\begin{array}{l}\text { Feed conversion efficiency } \\
\text { (FCE) }\end{array}$ & $40.00 \pm 11.18^{\mathrm{a}}$ & $1.95 \pm 0.39^{\mathrm{a}}$ \\
$\begin{array}{l}\text { Average daily gain } \\
\text { (\%ADG) }\end{array}$ & $3.33 \pm 0.33^{\mathrm{a}}$ & $1.19 \pm 0.12^{\mathrm{a}}$ \\
$\begin{array}{l}\text { Protein efficiency ratio } \\
\text { (PER) }\end{array}$ & $1.08 \pm 0.30^{\mathrm{a}}$ & $46.74 \pm 7.53^{\mathrm{a}}$ \\
$\begin{array}{l}\text { \% Survival rate } \\
\text { Hepato-somatic index } \\
\text { (HSI) }\end{array}$ & $100.00 \pm 0.00^{\mathrm{a}}$ & $3.23 \pm 0.68$ \\
\hline
\end{tabular}

superscripts in each row $(a, b, c)$ are significantly different $(p<0.05)$ 
Average Daily Gain (\%ADG)

The calculated mean \%ADG values for control and CPO incorporated diets fed fishes were $3.33 \pm 0.33 \%$ and $3.31 \pm 0.68 \%$ consecutively (Table 2 ) without significant differences.

\section{Protein Efficiency Ratio (PER)}

The calculated mean values of PER for the control and CPO diet fed fish were $1.08 \pm 0.30$ and $1.22 \pm 0.8$ (Table 2). In the present study, crude protein levels were $37.03 \pm 0.02$ and $37.11 \pm 0.04$ in control and CPO diets. PER is also influenced by digestibility and environmental conditions. According to the experiment conducted with Nile tilapia, $\mathrm{Hu}$ et al. (2006) reported that PER values were gradually increased with the diets supplemented with $\beta$ carotene. The results indicated that the addition of carotene rich sources did not affect none of the above parameters of fish (Bolger et al. 1989).

\section{Survival Rate (\%)}

The survival rate of fish for test diets of control and CPO were $100 \%$. (Bolger et al. 1989) have conducted a study using sex-reversed red tilapia to determine the effects of synthetic carotenoids of astaxanthin, zeaxanthin and $\beta$-carotene over spirulina incorporated diet, and results have shown that neither synthetic carotenoids nor spirulina carotenoid produced an effect on fish growth or survival.

Wang et al. (2006), who investigated whether the dietary carotenoid supplements could make differences in survival, growth, pigmentation and antioxidant capacity of characins Hyphessobrycon callistus, reported that there were no differences in growth and survival rate of the fish after 8 weeks in the experimental period. Also, body astaxanthin and $\beta$-carotene content have increased with increasing dietary carotenoid concentration (Wang et al. 2006).

\section{Hepato-Somatic Index (\%HSI)}

The mean value of HSI of fish fed with two diets of control and CPO showed $0.46 \pm 0.03$ and $0.60 \pm 0.04$ respectively (Table 2). Hepato-somatic index (HSI) is associated with the liver energetic reserves and metabolic activity (Ighwela et al. 2014). When the feed is available in large quantity and conditions are favourable, it causes to increase the HSI value. The diets do not effect of HSI or body weight on fish.

\section{Saponification value of oil}

The saponification value of $\mathrm{CPO}$ and palm olein were $192 \pm 0.1$ and $194 \pm 0.01$ in $\mathrm{mg} \mathrm{KOH} / \mathrm{g}$ respectively. The greater the molecular weight, the smaller number of fatty acids is liberated per gram of fat hydrolysed (Yanar et al. 2007).

\section{Carotenoids analysis}

Total carotenoid levels were $481.00 \pm 0.01$, $2.11 \pm 0.02$ for CPO, and palm olein, respectively before adding to feed. The highest was the CPO which was rich in $\beta$-carotenes. The variation of absorbance with the wavelength of each oil sample was shown in Figure 2. The highest total carotenoid level was shown by CPO (Table 3).

Table 3 Total carotenoids level in fish skin and flesh

\begin{tabular}{llll}
\hline Time & & Control & CPO \\
\hline Initial & Skin & $2.56 \pm 0.02^{\mathrm{a}}$ & $2.57 \pm 0.02^{\mathrm{a}}$ \\
& Flesh & $0.06 \pm 0.01^{\mathrm{a}}$ & $0.06 \pm 0.01^{\mathrm{a}}$ \\
3 weeks & Skin & $2.57 \pm 0.04^{\mathrm{b}}$ & $3.96 \pm 0.03^{\mathrm{a}}$ \\
& Flesh & $0.12 \pm 0.05^{\mathrm{b}}$ & $0.19 \pm 0.14^{\mathrm{a}}$ \\
5 weeks & Skin & $2.88 \pm 0.05^{\mathrm{b}}$ & $5.67 \pm 0.01^{\mathrm{a}}$ \\
& Flesh & $0.13 \pm 0.03^{\mathrm{b}}$ & $0.22 \pm 0.02^{\mathrm{a}}$ \\
& Skin & $3.24 \pm 0.02^{\mathrm{b}}$ & $6.06 \pm 0.03^{\mathrm{a}}$ \\
& Flesh & $0.14 \pm 0.03^{\mathrm{b}}$ & $0.28 \pm 0.01^{\mathrm{a}}$ \\
\hline
\end{tabular}

Means with different superscripts in each row $(a, b)$ are significantly different $(p<0.05)$ 
D.S.A.D.S. Wickramanayake et al.

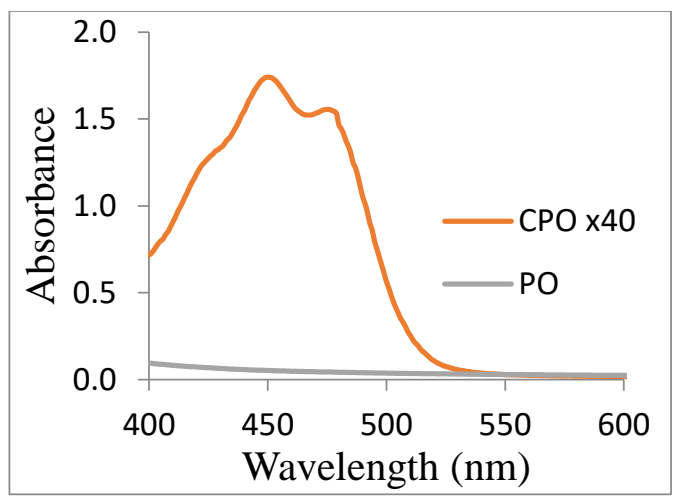

Figure 2 The variation of absorbance of CPO $(\times 40$ diluted with acetone $)$ and palm olein $((\times 10$ diluted with acetone) with wavelength.

As mentioned by Scott (2001), CPO shows three absorption maxima similar to pure $\beta$-carotene at 425, 450 and $478 \mathrm{~nm}$ (Figure 2). Palm olein does not show any absorption peaks within $400-500 \mathrm{~nm}$ range which proves that $\beta$-carotene level in palm olein is less than detectable limit (Top et al. 2011).

The highest level of carotenoids was accumulated in fish fed with CPO. The skin colour of fish fed with CPO remained largely unchanged although a slight pinkish colour could be observed in their skin. The highest triacylglycerol was obtained in fish fed with CPO (table 3).

Previous studies had been demonstrated that the dominant carotenoids in the flesh of Nile tilapia were astaxanthin and canthaxanthin. Violaxanthin was the second most important pigment identified in Nile tilapia skin followed by zeaxanthin (Sefc et al. 2014). Several studies have shown that dietary supply increases the integument concentration of carotenoids in cichlids (Brown et al. 2013; Güroy et al. 2007, 2012; Kaisuyama et al. 1988; Kop et al. 2008).

Most information on carotenoid metabolism in the cichlid integument comes from feeding experiments with Nile tilapia (Kaisuyama et al. 1988). The reconstructed metabolic pathways involve epimerization, reduction or oxidation of dietary canthaxanthin, astaxanthin, zeaxanthin and lutein. Dietary tunaxanthin accumulated in the integument without chemical modifications, whereas dietary $\beta$-carotene was neither accumulated nor bio converted in the integument (Kaisuyama et al. 1988). Consistent with the findings in tilapia, dietary $\beta$-carotene had smaller effects on skin coloration than astaxanthin. Similar Feeding experiments of with two cichlids Amphilophus citrinellus (Pan and Chien 2009) and Cichlasoma severum (Kop et al. 2008) had proved it.

The carotenoid deposition in flesh was significant over the skin of Nile tilapia. The carotenoids deposition was not evenly distributed in CPO fed fish fillets. As ventral part is thinner, it showed higher deposition than the dorsal part of the flesh. Reddish colour was observed closer to the caudal area than the anterior part due to the excess deposition of carotenoid pigment in that area. Previous studies by No and Storebakken (1991) have shown that caudal part of fish may contain 30$40 \%$ more carotenoids than the back and neck part of the fillet. Bjerkeng $(1992,2000)$ observed a longitudinal variation in carotenoid content and red colour of the fish flesh, which indicated that higher carotenoid deposition occurred in the caudal area than in anterior part of the body of salmonid fishes. This can occur due to the rapid deposition of carotenoids close to the backbone (Weerakkody and Cumaranathunga 2016). Fish fed with control diet containing palm olein also showed a slight carotenoid deposition in flesh. The carotenoids (specially carotene) other than $\beta$-carotene present in the palm olein might be the reason for giving a slight reddish colour to fillet in control tretment. It proved that $\beta$-carotene was not the only pigment responsible for flesh colouration in the present study. But carotenoids which are absent in palm olein (mainly $\beta$-carotene) might give more colouration in fish fed with CPO diet.

The sensory analysis component of the present study also indicates that sensory properties of fillet colour help to increase consumer attraction. A red colour fillet is more attractive and has a higher consumer preference in our sample population. Weerakkody and Cumaranatunga (2016) have conducted a study on carp fed with diets incorporating diets, and have revealed that there was a significantly higher carotenoid accumulation in flesh, as well as in skin.

Red porgy (Pagrus pagrus) fed with an astaxanthin-supplemented diet, $\beta$-carotene and lycopene supplemented diets led an increased total carotenoid content in the dorsal skin area (Chatzifotis et al. 2005).

Arous et al. (2014) reported that feed supplemented with $\beta$-carotene riched Dunaliella salina extract had given a reddish colour in red tilapia flesh. Similar studies were carried out by 


\section{D.S.A.D.S. Wickramanayake et al.}

Valente et al. (2016) showed that the total carotenoid concentration was the highest in the skin of Nile tilapia fed with 5\% Ulva spp. followed by $10 \%$ Ulva spp. In muscle samples, no carotenoids could be detected.

\section{CONCLUSIONS}

Total carotenoid levels of CPO is found about $13.627 \mu \mathrm{g} / \mathrm{g}$. A considerable increase of carotenoids in fish flesh was detected compared to the initial carotenoids content in flesh. Although skin color was not affected by $\beta$-carotene, flesh was affected significantly. The tested carotenoid sources of CPO can be used in the aquaculture industry to increase the consumer preferance and attraction for fish fillets. CPO can be used as natural plant based carotenoids to improve the colour of fish flesh.

\section{REFERENCES}

Aas, G.H., Bjerkeng, B., Storebakken, T. \& Ruyter, B. 1999. Blood appearance, metabolic transformation and plasma transport proteins of 14C-astaxanthin in Atlantic salmon (Salmo salar L.). Fish Physiology and Biochemistry 21(4): 325-334. https://doi.org/10.1023/A:100789022 4389

AOAC 2003, Official methods of analysis of the association of official analytical chemists. 17th edn. Association of Official Analytical Chemist, Arlington, Virginia.

Arous, W.H., El-Bermawi, N.M., Shaltout, O.E. \& Essa, M.A. 2014. Effect of Adding Different Carotenoid Sources on Growth Performance, Pigmentation, Stress Response and Quality in Red Tilapia (Oreochromis Spp). Middle East Journal of Applied Science 4(4): 988-999.

Bjerkeng, B. 2000. Carotenoid pigmentation of salmonid fishes-recent progress. pp. 71-89. In: Cruz -Suárez, L.E., Ricque-Marie, D., TapiaSalazar, M., Olvera-Novoa, M.A. y Civera-Cerecedo, R., (Eds.). Avances en Nutrición Acuícola V. Memorias del V Simposium Internacional de Nutrición Acuícola. 19-22 Noviembre, 2000. Mérida, Yucatán.

Bolger, T. \& Connolly, P.L. 1989. The selection of suitable indices for the measurement and analysis of fish condition. Journal of Fish Biology 34(2): 171-182. https://doi.org/10. 1111/j.1095-8649.1989.tb03300.x
Brown, A.C., McGraw, K.J. \& Clotfelter, E.D. 2013. Dietary carotenoids increase yellow nonpigment coloration of female convict cichlids (Amantitlania nigrofasciata). Physiological and Biochemical Zoology 86(3): 312-322. https://doi.org/10.1086/670734

Chatzifotis, S., Pavlidis, M., Jimeno, C. D., Vardanis, G., Sterioti, A. \& Divanach, P. 2005. The effect of different carotenoid sources on skin coloration of cultured red porgy (Pagrus pagrus). Aquaculture Research 36(15): 15171525. https://doi.org/10.1111/j.1365-2109.2005. 01374.x

Craig, S., Helfrich, L. A., Kuhn, D. \& Schwarz, M. H. 2017. Understanding fish nutrition, feeds, and feeding. Virginia State University Publication No. 420-256, Virginia State University, Virginia. $6 \mathrm{p}$.

Das, A.P. \& Biswas, S.P. 2016. Carotenoids and pigmentation in ornamental fish. Journal of Aquaculture and Marine Biology 4(5): 1-3. https://doi.org/10.15406/jamb.2016.04.00093

De Silva, S.S. \& Anderson, T.A. 1994. Fish Nutrition in Aquaculture. Springer Science \& Business Media, Dordrecht. 320 p.

Dedeke, G. A., Owa, S. O., Olurin, K. B., Akinfe, A. O. \& Awotedu, O. O. 2013. Partial replacement of fish meal by earthworm meal (Libyodrilus violaceus) in diets for African catfish, Clarias gariepinus. International Journal of Fisheries and Aquaculture 5(9): 229-233.

Folch, J., Lees, M. \& Stanley, G.S. 1957. A simple method for the isolation and purification of total lipides from animal tissues. Journal of Biological Chemistry 226(1): 497-509.

Foss, P., Storebakken, T., Schiedt, K., LiaaenJensen, S., Austreng, E. \& Streiff, K., 1984. Carotenoids in diets for salmonids: I. Pigmentation of rainbow trout with the individual optical isomers of astaxanthin in comparison with canthaxanthin. Aquaculture 41(3): 213-226.

García-Chavarría, M. \& Lara-Flores, M. 2013. The use of carotenoid in aquaculture. Research Journal of Fisheries and Hydrobiology 8(2): 3849.

Gouveia, L., Rema, P., Pereira, O. \& Empis, J. 2003. Colouring ornamental fish (Cyprinus carpio and Carassius auratus) with microalgal biomass. Aquaculture Nutrition 9(2): 123-129. 
D.S.A.D.S. Wickramanayake et al.

https://doi.org/10.1046/j.1365-2095.2003.0023 3.x

Gupta, S.K., Jha, A.K., Pal, A.K. \& Venkateshwarlu, G., 2007. Use of natural carotenoids for pigmentation in fishes. Indian Journal of Natural Products and Resources 6(1): 46-49. Zeb, A. \& Mehmood, S. 2004. Carotenoids contents from various sources and their potential health applications. Pakistan Journal of Nutrition 3(3): 199-204. https://doi.org/10.3923/pjn.2004.199.204

Güroy, B., Şahin, İ., Mantoğlu, S., \& Kayalı, S. 2012. Spirulina as a natural carotenoid source on growth, pigmentation and reproductive performance of yellow tail cichlid Pseudotropheus acei. Aquaculture International 20(5): 869-878. https://doi.org/10.1007/s10499012-9512-x

Güroy, B.K., Cirik, Ş., Güroy, D., Sanver, F. \& Tekinay, A.A. 2007. Effects of Ulva rigida and Cystoseira barbata meals as a feed additive on growth performance, feed utilization, and body composition of Nile tilapia, Oreochromis niloticus. Turkish Journal of Veterinary and Animal Sciences 31(2): 91-97.

Hu, C. J., Chen, S.M., Pan, C.H. \& Huang, C.H. 2006. Effects of dietary vitamin A or $\beta$-carotene concentrations on growth of juvenile hybrid tilapia, Oreochromis niloticus $\times O$. aureus. Aquaculture 253(1-4): 602-607. https://doi.o $\mathrm{rg} / 10.1016 /$ j.aquaculture.2005.09.003

Ighwela, K.A., Ahmad, A.B. \& Abol-Munafi, A.B. 2014. The selection of viscerosomatic and hepatosomatic indices for the measurement and analysis of Oreochromis niloticus condition fed with varying dietary maltose levels. International Journal of Fauna and Biological Studies 1(3): 18-20.

Jain, M. K., Mehta, N. J., Fonseca, M. M. \& Pai, N. V. 1990. Correlation of serum vitamin A and its transport protein (RBP) in malnourished and vitamin A deficient children. Journal of Postgraduate Medicine 36(3): 119-123.

Jintasataporn, O. \& Yuangsoi, B. 2012. Stability of carotenoid diets during feed processing and under different storage conditions. Molecules 17(5): 5651-5660. https://doi.org/10.3390/mo lecules 17055651

Kaisuyama, M. \& Matsuno, T. 1988. Carotenoid and vitamin $\mathrm{A}$, and metabolism of carotenoids, $\beta$-carotene, canthaxanthin, astaxanthin, zeaxanthin, lutein and tunaxanthin in tilapia Tilapia nilotica. Comparative Biochemistry and Physiology Part B: Comparative Biochemistry 90(1): 131-139. https://doi.org/10.1016/03050491(88)90049-1

Kalinowski, C.T., Robaina, L.E., FernandezPalacios, H., Schuchardt, D. \& Izquierdo, M.S. 2005. Effect of different carotenoid sources and their dietary levels on red porgy (Pagrus pagrus) growth and skin colour. Aquaculture 244(1-4): 223-231. https://doi.org/10.1016/j.aquaculture. 2004.11.001

Kang, D.S. \& Ha, B.S. 1994. Metabolism of dietary carotenoids and effects to intensify the body color of cultured sea bass. Korean Journal of Fisheries and Aquatic Science 27(3): 272-281.

Kop, A. \& Durmaz, Y. 2008. The effect of synthetic and natural pigments on the colour of the cichlids (Cichlasoma severum sp., Heckel 1840). Aquaculture International 16(2): 117-122. https://doi.org/10.1007/s10499-007-9130-1

Koushki, M., Nahidi, M. \& Cheraghali, F. 2015. Physico-chemical properties, fatty acid profile and nutrition in palm oil. Archives of Advances in Biosciences 6(3): 117-134.

Luzzana, U., Coutteau, P. \& BAVEVI, L. 2003. Nutritional solutions to winter syndrome in gilthead seabrem: Verification at a cage farm in Croatia. Aquafeeds International 6: 14-18.

Mancini, A., Imperlini, E., Nigro, E., Montagnese, C., Daniele, A., Orrù, S. \& Buono, P. 2015. Biological and nutritional properties of palm oil and palmitic acid: effects on health. Molecules 20(9): 17339-17361. https://doi.org/10.3390/ molecule s200917339

No, H. K. \& Storebakken, T. 1991. Pigmentation of rainbow trout with astaxanthin at different water temperatures. Aquaculture 97(2-3): 203-216. https://doi.org/10.1016/0044-8486(91)90265-9 Bjerkeng, B. 1992. Analysis of carotenoids in salmonids: Quality assurance in the fish industry. Aquaculture 101: 417-425.

Pan, C.H. \& Chien, Y.H. 2009. Effects of dietary supplementation of alga Haematococcus pluvialis (Flotow), synthetic astaxanthin and $\beta$ carotene on survival, growth, and pigment distribution of red devil, Cichlasoma citrinellum (Günther). Aquaculture Research 40(8): 871879. https://doi.org/10.1111/j.1365-2109.2008.0 2153.x 
Rebecca, L.J., Sharmila, S., Das, M.P. \& Seshiah, C. 2014. Extraction and purification of carotenoids from vegetables. Journal of Chemical and Pharmaceutical Research 6(4): 594-598.

Sadekarpawar, S. \& Parikh, P. 2013. Gonadosomatic and hepatosomatic indices of freshwater fish Oreochromis mossambicus in response to a plant nutrient. World Journal of Zoology 8(1): 110-118.

Scott, K.J. 2001. Detection and measurement of carotenoids by UV/VIS spectrophotometry. Current Protocols in Food Analytical Chemistry (1): F2-2. https://doi.org/10.1002/0471142913 .faf0202s00

Sefc, K.M., Brown, A.C. \& Clotfelter, E.D. 2014. Carotenoid-based coloration in cichlid fishes. Comparative Biochemistry and Physiology Part A: Molecular and Integrative Physiology 173: 42-51. https://doi.org/10.1016/j.cbpa.2014.03.0 06

Selvakumar, D. \& Kandasamy, D. 2011. Application of microbial carotenoids as a source of colouration and growth of ornamental fish Xiphophorus helleri. World Journal of Fish and Marine Sciences 3(2): 137-144.

Top, A.G., Muhamad, H., Abdullah, A., Sani, H.A. \& Dauqan, E. 2011. Vitamin E and beta carotene composition in four different vegetable oils. American Journal of Applied Sciences 8(5): 407-412. https://doi.org/10.3844/ajassp.2011.40 7.412

Valente, L. M., Araújo, M., Batista, S., Peixoto, M. J., Sousa-Pinto, I., Brotas, V. \& Rema, P. 2016. Carotenoid deposition, flesh quality and immunological response of Nile tilapia fed increasing levels of IMTA-cultivated Ulva spp. Journal of Applied Phycology 28(1): 691-701. https://doi.org/10.1007/s10811-015-0590-9

Wang, Y.J., Chien, Y.H. \& Pan, C.H. 2006. Effects of dietary supplementation of carotenoids on survival, growth, pigmentation, and antioxidant capacity of characins, Hyphessobrycon callistus. Aquaculture 261(2): 641-648. https://doi.org/ 10.1016/j.aquaculture.2006.08.040

Weerakkody, W. \& Cumaranatunga, P.R.T. 2016. Effects of dried, powdered carrot (Daucus carota) incorporated diet on the skin and flesh colouration of Catla catla. Sri Lanka Journal of Aquatic Sciences 21(2): 95-103. https://do i.org/10.4038/sljas.v21i2.7505

Yanar, Y., Büyükçapar, H., Yanar, M. \& Göcer, M. 2007. Effect of carotenoids from red pepper and marigold flower on pigmentation, sensory properties and fatty acid composition of rainbow trout. Food Chemistry 100(1): 326-330. https://doi.org/10.1016/j.foodchem.2005.09.056

Yanar, Y., Büyükçapar, H., Yanar, M. \& Göcer, M. 2007. Effect of carotenoids from red pepper and marigold flower on pigmentation, sensory properties and fatty acid composition of rainbow trout. Food Chemistry 100(1): 326-330. https://doi.org/10.1016/j.foodchem.2005.09.056 ASTM D5558-95 2017. Standard Test Method for Determination of the Saponification Value of Fats and Oils, ASTM International, West Conshohocken, PA.

Zaliha, O., Elina, H., Miskandar, M.S., Siti, H., Noor, L., Muhammad, R.R. \& Norizzah, A.R., 2015. Palm oil crystallisation: a review. Journal of Oil Palm Research 27(2): 97-106. 